\title{
Expression and enzymatic activity of dipeptidyl peptidase-IV in human astrocytic tumours are associated with tumour grade
}

\author{
JARMILA STREMENOVA ${ }^{1}$, EVZEN KREPELA ${ }^{1}$, VLADISLAV MARES ${ }^{2}$, JULIE TRIM ${ }^{3}$, VLADIMIR DBALY ${ }^{4}$, \\ JOSEF MAREK $^{4}$, ZDISLAVA VANICKOVA ${ }^{1}$, VERA LISA ${ }^{2}$, CHRIS YEA $^{3}$ and ALEKSI SEDO $^{1}$ \\ ${ }^{1}$ Joint Laboratory of Cancer Cell Biology of the 1st Faculty of Medicine, Charles University in Prague, \\ and the ${ }^{2}$ Institute of Physiology, Academy of Sciences, Prague, Czech Republic; ${ }^{3}$ Ferring Pharmaceuticals, \\ Southampton, UK; ${ }^{4}$ Departments of Neurosurgery and Pathology, Hospital Na Homolce, Prague, Czech Republic
}

Received April 23, 2007; Accepted June 22, 2007

\begin{abstract}
Alterations in dipeptidyl peptidase-IV (DPP-IV) enzymatic activity are characteristic of malignant transformation. Through its well-characterized functionality in regulating the activity of bioactive peptides by removal of the N-terminal dipeptide, DPP-IV activity may have profound effects upon metastatic potential and cell growth. Although DPP-IV/CD26 (EC 3.4.14.5) is the canonical representative of the group, a number of other proteins including DPP-7, 8, 9, and seprase/fibroblast activation protein- $\alpha$ (FAP- $\alpha$ ) have been shown to have similar enzymatic activity. This study was set up to address the relative representation and enzymatic activity of plasma membrane localized DPP-IV/CD26 and FAP- $\alpha$ in human brain and astrocytic tumours. In parallel, expression of CXCR4, receptor for glioma cell growth stimulator chemokine SDF-1 $\alpha$ known to be a DPP-IV substrate, was investigated. This is the first report showing that non-malignant brain tissue contains a DPP-IV-like enzymatic activity attributable mostly to DPP-8/9, while the substantial part of the activity in glioma is due to increased DPP-IV/CD26, localized in both the vascular and parenchymal compartments. DPP-IV enzymatic activity increased dramatically with tumour grade severity. A grade-related increase in CXCR4 receptor paralleled the rise in DPP-IV expression and activity. These data might support a role for DPP-IV regulation of the CXCR4-SDF- $1 \alpha$ axis in glioma development.
\end{abstract}

\section{Introduction}

Malignant gliomas, characterized as highly proliferative and locally invasive neoplasias, account for more than $50 \%$

Correspondence to: Dr Aleksi Sedo, 1st Faculty of Medicine, Charles University in Prague, U Nemocnice 5, 128 53, Prague 2, Czech Republic

E-mail: aleksi@cesnet.cz

Key words: glioma, glioblastoma, dipeptidyl peptidase, DASH, chemokine, stromal cell-derived factor of central nervous system tumours. Despite intensive basic research and efforts in the fields of therapeutic regimens and modalities, prognosis of patients suffering from these tumours remains dismal. A major area of current investigation is identification of alterations in mRNA and protein expression in glioma cells that might contribute to gliomagenesis and also be amenable as therapeutic targets.

Dipeptidyl peptidase-IV (DPP-IV/CD26) is a multifunctional, typically plasma membrane localized protein, widely distributed in various cell systems. It has been for years believed to be a unique protease cleaving peptides and proteins with a proline residue on the penultimate position from their N-terminal. Subsequently, other 'DPP-IV activity and/or structure-homologues' (DASH), were discovered (1). Together with CD26, the canonical DPP-IV, enzymatically active DASH include plasma membrane fibroblast activation protein- $\alpha$ (FAP- $\alpha)$ and the intracellular DPPs-7, 8, 9. Because of their similar enzymatic activity, it is tempting to speculate on their participation in or interference with biological function(s) previously attributed solely to DPP-IV/CD26 although relative activity will be a function of local DASH involvement. Among the multiple physiological and pathological functions so far described, DPP-IV may play a critical role in immunoregulation as well as in carcinogenesis (2-5). In contrast to the proteases involved in structural protein degradation during malignant progression, plasma membrane associated DPP-IV/CD26 probably function dominantly as the regulators of humoral signaling. As such, they participate in postsecretory processing of biologically active peptides implicated in control of cell growth, migration and invasion. Thus, although some biological functions of DPP-IV seem to be independent of its intrinsic hydrolytic activity (6), limited proteolysis of DASH substrates such as substance P, neuropeptide Y, and RANTES and SDF-1 $\alpha$ chemokines appears to be critical for quantitative and also qualitative changes of their signaling potential (5).

Chemokine SDF-1 $\alpha$ together with its cognate receptor CXCR4 is functionally involved in several cancer progressionrelated events including chemotaxis, invasion, adhesion and vascularization $(7,8)$ in a variety of malignant tumours $(9-11)$. In glioma cells, CXCR4 represents the major chemokine receptor mediating their survival $(12,13)$. DPP-IV enzymatic 
activity is responsible for cleavage of SDF- $1 \alpha$ at its aminoterminal consensus sequence. Truncation of SDF-1 $\alpha$ by DPPIV-like activity inhibits chemotactic activity, while the resulting fragment may even act as an antagonist of CXCR4 (14). Codistribution of DPP-IV with CXCR 4 and their SDF- $1 \alpha$ induced internalization has been observed in human lymphocytes and in several cell lines (15). Such orchestrated regulation of DPP-IV hydrolytic potential within the CXCR4-SDF-1 $\alpha$ regulatory axis might serve as an example of the putative regulatory 'DASH system' (5), consisting of plasma membrane localized DPP-IV enzymatic activity-bearing molecules, their biologically active autocrine/paracrine substrates and relevant receptors.

While DPP-IV has been studied in numerous cancer types, there are no reports of DPP-IV activity in human brain and astrocytic tumours, despite the importance of SDF- $1 \alpha$ CXCR 4 in glioma development and DPP-IV regulation of SDF- $1 \alpha$ activity. In this study, we ascertain the relative representation and enzymatic activities of DPP-IV-like proteases in normal brain and astrocytomas of varying grades, and relate this to the presence of SDF- $1 \alpha$ receptor CXCR4.

\section{Materials and methods}

Patients, sample preparation and characterization. Tumour specimens were collected from 31 patients undergoing astrocytic tumour resection. Tumours were graded in compliance with the current WHO Classification Criteria. Non-tumorous brain specimens were obtained from eleven patients in whom brain surgery was performed for drug-resistant temporal lobe epilepsy (Table I). Tissue samples, clear of macroscopic vessels and necrosis, were frozen on solid $\mathrm{CO}_{2}$ and then stored at $-80^{\circ} \mathrm{C}$. Vascularization and necrotic areas in paraffin sections were scored semi-quantitatively on a 5-titered scale (0-4 crosses) and expressed as the average calculated from the individual values of each optical field determined. Written informed consent was obtained from the patients before their entry into the study, according to the guidelines of institutional Ethics Committee.

Isolation and quantification of total RNA. Total RNA was isolated using the TRIzol Reagent (Invitrogen, Paisley, UK) according to the manufacturer's instructions. Spectrophotometric analysis, carried out in $10 \mathrm{mM}$ Tris- $\mathrm{HCl}$ buffer, $\mathrm{pH} 7.5$, confirmed that the samples of total RNA had an $\mathrm{A}_{260 \mathrm{~nm}} / \mathrm{A}_{280 \mathrm{~nm}}$ ratio $>1.8$. The concentration of total RNA was determined using the RiboGreen RNA Quantitation Kit (Molecular Probes, Eugene, OR, USA).

Real-time RT-PCR. Gene coding region-specific oligonucleotide primers and fluorogenic TaqMan probes for the real-time RT-PCR assays of expression of the investigated transcripts were designed with the program Primer Express (Applied Biosystems, Foster City, USA) and were synthesized at Proligo (Paris, France) and Applied Biosystems (Warrington, UK), respectively. The sequences and final concentrations of the primers and probes that were used in the real-time RT-PCR assays are indicated in Table II. The expression of DPPIV, FAP- $\alpha$, and CXCR4 mRNAs and $\beta$-actin mRNA (internal reference transcript) was quantified by coupled
Table I. Characterization of the experimental cohort.

\begin{tabular}{|c|c|c|c|c|c|}
\hline Diagnosis & $\begin{array}{l}\text { Patient } \\
\text { code }\end{array}$ & Age & Sex & Vascularisation & Necrosis \\
\hline \multirow[t]{11}{*}{ Control } & 26 & 46 & $\mathrm{~F}$ & 1 & 0 \\
\hline & 27 & 29 & $\mathrm{~F}$ & 1 & 0 \\
\hline & 43 & 44 & M & 0 & 0 \\
\hline & 45 & 43 & M & 0 & 0 \\
\hline & 46 & 54 & $\mathrm{~F}$ & 0 & 0 \\
\hline & 48 & 34 & $\mathrm{~F}$ & 0 & 0 \\
\hline & 49 & 30 & M & 1 & 0 \\
\hline & 50 & 50 & M & 0 & 0 \\
\hline & 53 & 40 & $\mathrm{~F}$ & 0 & 0 \\
\hline & 7 & 72 & M & ND & ND \\
\hline & $5 \mathrm{~A}$ & 34 & M & 0 & 0 \\
\hline \multirow[t]{3}{*}{ Grade II } & 5 & 34 & M & 1 & 0 \\
\hline & 11 & 34 & $\mathrm{~F}$ & 1 & 0 \\
\hline & 19 & 34 & $\mathrm{~F}$ & 1 & 0 \\
\hline \multirow[t]{4}{*}{ Grade III } & 2 & 25 & M & 1 & 0 \\
\hline & 15 & 68 & M & 1 & 1 \\
\hline & 16 & 52 & M & 2 & 1 \\
\hline & 55 & 33 & M & 2 & 0 \\
\hline \multirow[t]{24}{*}{ Grade IV } & 1 & 70 & M & 2 & 2 \\
\hline & 3 & 53 & $\mathrm{~F}$ & 2 & 0 \\
\hline & 4 & 52 & $\mathrm{~F}$ & 2 & 1 \\
\hline & 6 & 54 & $\mathrm{~F}$ & 2 & 1 \\
\hline & 9 & 59 & $\mathrm{~F}$ & 1 & 0 \\
\hline & 10 & 48 & $\mathrm{~F}$ & 3 & 2 \\
\hline & 12 & 57 & $\mathrm{~F}$ & 3 & 2 \\
\hline & 13 & 32 & M & 3 & 1 \\
\hline & 14 & 70 & M & 3 & 1 \\
\hline & 22 & 49 & $\mathrm{M}$ & 3 & 3 \\
\hline & 25 & 67 & $\mathrm{~F}$ & 2 & 2 \\
\hline & 28 & 72 & $\mathrm{~F}$ & 2 & 1 \\
\hline & 29 & 67 & $\mathrm{~F}$ & 2 & 1 \\
\hline & 31 & 46 & M & 3 & 3 \\
\hline & 32 & 65 & $\mathrm{~F}$ & 3 & 1 \\
\hline & 33 & 62 & M & 2 & 4 \\
\hline & 35 & 73 & $\mathrm{~F}$ & 2 & 1 \\
\hline & 36 & 32 & $\mathrm{~F}$ & 2 & 4 \\
\hline & 37 & 32 & $\mathrm{~F}$ & ND & ND \\
\hline & 39 & 33 & $\mathrm{~F}$ & 2 & 0 \\
\hline & 40 & 55 & $\mathrm{M}$ & 1 & 3 \\
\hline & 42 & 57 & $\mathrm{~F}$ & 2 & 0 \\
\hline & 44 & 61 & $\mathrm{M}$ & 2 & 1 \\
\hline & 47 & 66 & $\mathrm{~F}$ & 2 & 2 \\
\hline
\end{tabular}

ND, not determined. 
Table II. Primers and TaqMan probes used for real-time RT-PCR quantitation of expression of the investigated transcripts.

\begin{tabular}{|c|c|c|}
\hline Transcript & $\begin{array}{c}\text { GeneBank } \\
\text { accession no. }\end{array}$ & Sequences and final concentration of primers and TaqMan probes \\
\hline DPP-IV & NM_001935 & $\begin{array}{l}\text { Forward primer: 5'-TGGAAGGTTCTTCTGGGACTG-3', } 200 \mathrm{nM} \\
\text { Reverse primer: 5'-GATAGAATGTCCAAACTCATCAAATGT-3', } 200 \mathrm{nM} \\
\text { TaqMan probe: 5'-(6-FAM)CACCGTGCCCGTGGTTCTGCT(TAMRA)-3', } 200 \mathrm{nM}\end{array}$ \\
\hline FAP- $\alpha$ & NM_004460 & $\begin{array}{l}\text { Forward primer: 5'-TGCCACCTCTGCTGTGC-3', } 200 \mathrm{nM} \\
\text { Reverse primer: 5'-GAAGCATTCACACTTTTCATGGT-3', } 200 \mathrm{nM} \\
\text { TaqMan probe: 5'-(6-FAM)TGCATTGTCTTACGCCCTTCAAGAGTTC(TAMRA)-3', } 200 \mathrm{nM}\end{array}$ \\
\hline CXCR4 & NM_001008540 & $\begin{array}{l}\text { Forward primer: 5'-CATGGGTTACCAGAAGAAACTGA-3', } 400 \mathrm{nM} \\
\text { Reverse primer: 5'-GACTGCCTTGCATAGGAAGTTC-3', } 400 \mathrm{nM} \\
\text { TaqMan probe: 5'-(6-FAM)CACCTGTCAGTGGCCGACCTCCT(TAMRA)-3', } 200 \mathrm{nM}\end{array}$ \\
\hline B-actin & NM_001101 & $\begin{array}{l}\text { Forward primer: 5'-CTGGCACCCAGCACAATG-3', } 200 \mathrm{nM} \\
\text { Reverse primer: 5'-GGGCCGGACTCGTCATAC-3', } 200 \mathrm{nM} \\
\text { TaqMan probe: 5'-(VIC)AGCCGCCGATCCACACGGAGT(TAMRA)-3', } 200 \mathrm{nM}\end{array}$ \\
\hline
\end{tabular}

real-time RT-PCR assay. The RT-PCR reaction mixtures of a total volume of $50 \mu 1$ contained $25 \mu 1$ of ThermoScript Reaction Mix (a buffer with $3 \mathrm{mM} \mathrm{MgSO}_{4}$ and $0.2 \mathrm{mM}$ of each dGTP, dCTP, dATP and dTTP) and $1 \mu 1$ of ThermoScript Plus Reverse Transcriptase/Platinum Taq DNA polymerase Mix (Platinum Quantitative RT-PCR ThermoScript One-Step System, Invitrogen), the respective gene-specific primers and TaqMan probe at the indicated final concentrations (Table II), 40 U of RNase inhibitor RNaseOUT (Invitrogen), and $200 \mathrm{ng}$ of total RNA. The final concentrations of the primers and TaqMan probe adopted for real-time RT-PCR quantification of each indicated transcript were determined in optimization experiments. The real-time RT-PCR assays were run in duplicate in MicroAmp Optical 96-well Reaction Plates on the ABI PRISM 7700 Sequence Detection System using Sequence Detection System software (Applied Biosystems). The reverse transcription was carried out at $58^{\circ} \mathrm{C}$ for $30 \mathrm{~min}$ and the subsequent PCR amplification included a hot start at $95^{\circ} \mathrm{C}$ for $5 \mathrm{~min}, 45$ cycles of denaturation at $95^{\circ} \mathrm{C}$ for $15 \mathrm{sec}$ and of annealing/extension at $58^{\circ} \mathrm{C}$ for $1 \mathrm{~min}$. The threshold cycle $\left(\mathrm{C}_{\mathrm{T}}\right)$ values of the amplification reactions, represented by the plots of background-subtracted fluorescence intensity $(\Delta \mathrm{FI})$ of the reporter dye (6-FAM or VIC) against PCR cycle number, were determined with the Sequence Detection System software. The statistical difference of the B-actin mRNA-normalized target transcript expression in tumour and normal tissues was calculated from the linearized $\Delta \mathrm{C}_{\mathrm{T}}$ data (i.e. $2^{-\Delta \mathrm{C}_{\mathrm{T}}}$ ) and the tumour/normal ratio of the $B$-actin mRNA-normalized target transcript expression was calculated by means of the $2^{-\Delta \Delta \mathrm{C}_{\mathrm{T}}}$ method (16).

DPP-IV enzymatic activity biochemical assay. Tissue samples were homogenized in ice-cold phosphate buffered saline (PBS), pH 6.0, with an Ultra-Turrax homogenizer fitted with an S8N-5G probe (IKA, Staufen, Germany) and used for assay immediately. DPP-IV-like enzymatic activities were determined by continuous rate fluorimetric assay (17) with 7-(Glycyl-L-Prolylamido)-4-methylcoumarin (GlyPro-NHMec) and with H-7-(L-Lysyl-L-alanylamido)-4methylcoumarin (Lys-Ala-NHMec) (Bachem AG, Switzerland) as substrates respectively at a final concentration of $50 \mu \mathrm{M}$. The assays were performed in PBS of $\mathrm{pH} 7.4$ and in citrate/ $\mathrm{Na}_{2} \mathrm{HPO}_{4}$ buffer of $\mathrm{pH} 5.5$. The release of 4-Amino-7methylcoumarin was monitored at 380-nm excitation and 460-nm emission wavelengths (spectrofluorimeter PerkinElmer LS50B, USA). Selective DPP-IV, DPP-II and DPP8/9 inhibitors (Ferring Pharmaceuticals, UK) were used at the final concentration of $250 \mathrm{nM}$. Total protein concentration in samples was assayed according to Lowry (18).

DPP-IV enzymatic activity histochemistry. DPP-IV-like catalytic histochemistry was performed according to Lojda (19) in $10-\mu \mathrm{m}$ cryostat sections cut at $-20^{\circ} \mathrm{C}$ (Bright Instrument Company Ltd., Huntingdon, UK). The sections were fixed in a 1:1 mixture of acetone and chloroform for 2 min at $4^{\circ} \mathrm{C}$ and were incubated with Gly-Pro-4-methoxy- $\beta$-naphtylamide $\left(0.83 \times 10^{-3} \mathrm{M}\right)$ as a substrate (Bachem, Bubendorf, Switzerland) and Fast Blue $\mathrm{B}$ in $\mathrm{PBS}$ of $\mathrm{pH} 7.4$ at $4^{\circ} \mathrm{C}$. In controls, the DPP-IV substrate was omitted from the incubation medium.

Immunohistochemistry. Detection of DPP-IV/CD26, FAP- $\alpha$ and CXCR4 was performed in cryostat sections preincubated in $3 \%$ of heat-inactivated bovine foetal serum for $20 \mathrm{~min}$, followed by overnight incubation at $4^{\circ} \mathrm{C}$ with the respective primary antibodies: mouse monoclonal anti-human CD26 (1:100, clone M-A261), rabbit polyclonal anti-human CXCR4 (1:200) from Acris, Germany and mouse monoclonal antihuman FAP- $\alpha$ (1:200, clone F11-24, Alexis Biochemical, USA). This was followed by incubation with anti-mouse(1:200, Sigma, USA) or anti-rabbit (1:200, Sigma, USA) 
Table III. Correlations of clinical, morphological and biochemical characteristics of human astrocytic tumours and non-tumorous brain tissues.

\begin{tabular}{|c|c|c|c|c|c|c|c|}
\hline & $\begin{array}{l}\text { mRNA } \\
\text { FAP- } \alpha\end{array}$ & $\begin{array}{l}\text { mRNA } \\
\text { CXCR4 }\end{array}$ & $\begin{array}{c}\text { Total } \\
\text { DPP-IV-like } \\
\text { activity }\end{array}$ & $\begin{array}{c}\text { Activity after } \\
\text { DPP-IV } \\
\text { inhibition }\end{array}$ & $\begin{array}{c}\text { Activity after } \\
\text { DPP8/9 } \\
\text { inhibition }\end{array}$ & Vascularization & Necroses \\
\hline mRNA DPP-IV & 0.471 & 0.617 & 0.590 & -0.621 & 0.458 & 0.531 & 0.648 \\
\hline mRNA FAP- $\alpha$ & & 0.522 & 0.319 & -0.327 & ns & 0.403 & 0.357 \\
\hline mRNA CXCR4 & & & 0.639 & -0.387 & ns & 0.647 & 0.657 \\
\hline Total DPP-IV-like activity & & & & -0.452 & ns & 0.769 & 0.758 \\
\hline $\begin{array}{l}\text { Activity after DPP-IV } \\
\text { inhibition }\end{array}$ & & & & & -0.565 & -0.452 & -0.356 \\
\hline $\begin{array}{l}\text { Activity after DPP8/9 } \\
\text { inhibition }\end{array}$ & & & & & & ns & ns \\
\hline Vascularization & & & & & & & 0.712 \\
\hline
\end{tabular}

Spearman's correlation coefficients; probability of correlations: ns, $\mathrm{p}>0.05$; normal font, $\mathrm{p}<0.05$; bold font, $\mathrm{p}<0.01$.

IgG-FITC conjugates respectively. In controls, the primary antibodies were omitted from the medium.

The enzyme histochemistry and the immunohistochemistry sections were mounted in antifading Gel/Mount (Biomeda Corp., USA) and examined by transmission or fluorescence microscopy (Axiophot, Zeiss-Opton, Germany). Staining intensity was scored semi-quantitatively on a subjectively determined 5-titered scale ( $0-4$ crosses) relative to the negative staining controls, averaged from 10 segments of 2-3 nonsequentional histological sections

Statistical analysis. Statistica 6.0 sofware (StatSoft, Inc. Tulse, OK, USA) was used to perform statistical calculations. Differences between groups were evaluated with MannWhittney test; correlations were analyzed by means of Spearman's correlation coefficient (Table III).

\section{Results}

Co-expression of both plasma membrane-bound DPP-IV and FAP- $\alpha$, together with the robust expression of chemokine receptor CXCR4 mRNA was observed in all tissue samples analyzed. Although there were significant relative variations between tumours a significant upregulation of both DPP-IV and FAP $-\alpha$ mRNA expression was found in WHO grade IV glioma (Fig. 1). Furthermore, expression of DPP-IV and FAP- $\alpha$ transcripts was significantly correlated (Table III). Expression level of CXCR4 mRNA tightly correlated with the WHO glioma grade as well and with both DPP-IV and FAP- $\alpha$ mRNA expression (Table III).

Figure 1. Expression of DPP-IV, FAP- $\alpha$ and CXCR4 mRNA in glioma. Squares, medians; boxes, middle $25-75 \%$ of measured values; bars, minimal resp maximal values; $\circ$, remote values; $\bullet$, extreme values; $p$, compared to controls; ${ }^{*} \mathrm{p}<0.05,{ }^{* *} \mathrm{p}<0.01$; Mann-Whitney U test.
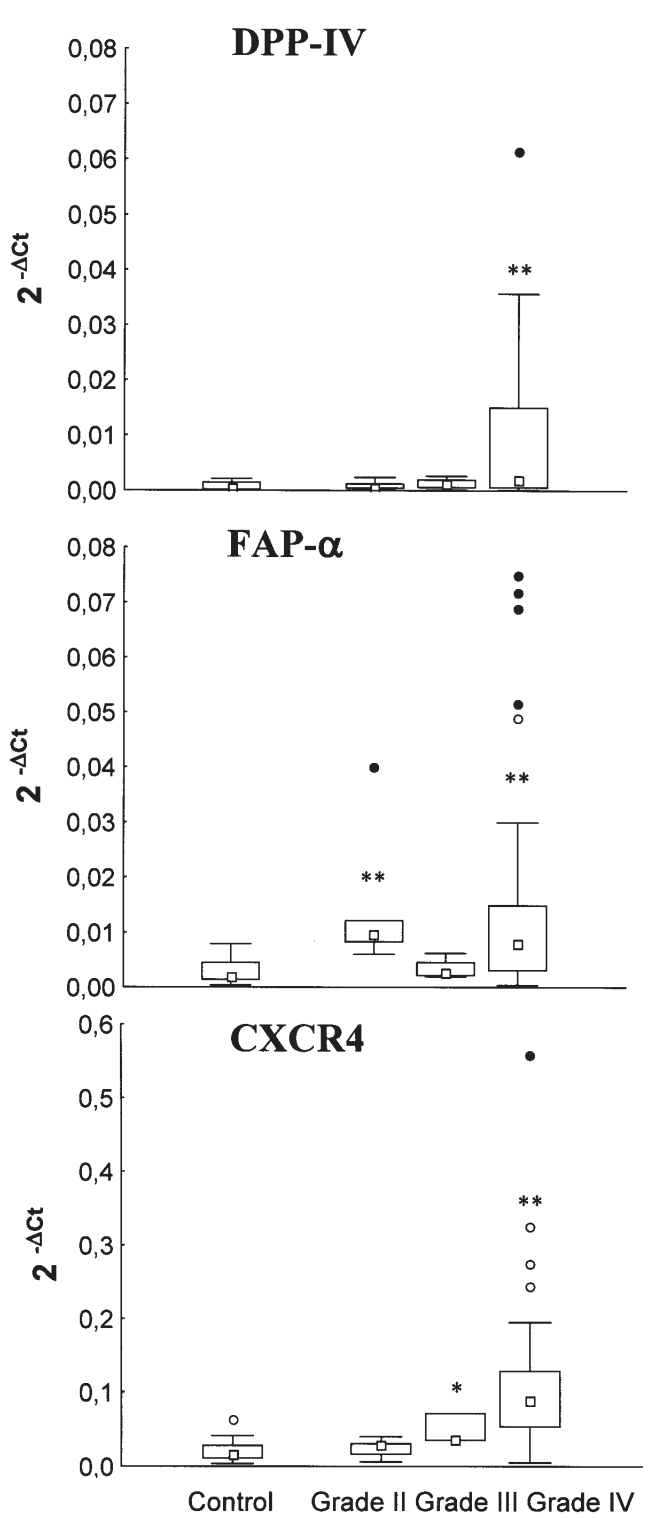


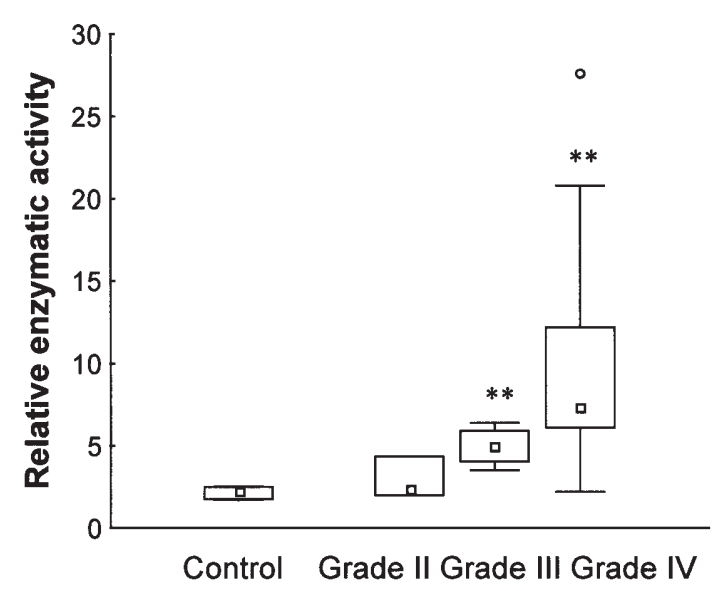

Figure 2. DPP-IV-like enzymatic activity per mg of protein in glioma. Squares, medians; boxes, middle $25-75 \%$ of measured values; bars, minimal resp maximal values; $\circ$, remote values; $\mathrm{p}$, compared to controls; ${ }^{* *} \mathrm{p}<0.01$; MannWhitney U test.

Although DPP-IV-like enzymatic activity varied within the individual tumours, it was significantly higher in highgrade tumours compared to the non-malignant brain tissues (Fig. 2). The entire DPP-IV-like enzymatic activity correlated with FAP- $\alpha$ and even more significantly with DPP-IV/CD26 mRNA expression. In addition, DPP-IV-like enzymatic activity tightly correlated with CXCR4 mRNA expression (Table III).

To assess the relative participation of plasma membrane associated DASH molecules to the whole DPP-IV-like enzymatic activity present in the tissue samples, inhibition studies using selective inhibitors were performed. Using an inhibitor with 60-fold higher potency for DPP-IV/CD26 than for DPP8/9 (20), the DPP-IV-like enzymatic activity was more profoundly inhibited in astrocytic tumours of all WHO grades than that in non-malignant brain (Fig. 3). In contrast, no such differential inhibition was seen using an inhibitor possessing 50-fold higher potency for DPP8/9 than for
DPP-IV (Fig. 3). Residual enzymatic activity after DPP8/9 inhibition correlated positively with mRNA expression of DPP-IV/CD26 (Table III). In line with that, the residual enzymatic activity after DPP-IV inhibition correlated inversely with both total DPP-IV-like enzymatic activity and with DPP-IV/CD26 mRNA expression (Table III). Together, results of expression and inhibition studies suggest the major part of DPP-IV-like hydrolytic activity is carried by intracellular DPP8/9 in non-malignant tissues as well as in gliomas irrespective of their WHO grade. In contrast with that, enzymatic activity of plasma membrane associated DPP-IV and FAP- $\alpha$ seem to grow gradually along with the tumour WHO grade.

Inhibitor of DPP-II, which is intracellular and prefers an acidic $\mathrm{pH}$, was devoid of virtually any effect on the enzymatic assays with Gly-Pro-NHMec as a substrate at $\mathrm{pH} 7.5$, suggesting the lack of DPP-II contribution to the overall DPP-IV-like enzymatic activity. In addition, the DPP-II inhibitor negligibly affected enzymatic reactions with Lys-Ala-NHMec run at $\mathrm{pH} 5.5$, i.e. in conditions typically preferred by DPP-II (not shown).

To characterize the tissue distribution of DPP-IV/CD26, FAP- $\alpha$ and CXCR4, enzymatic activity histochemistry and immunohistochemistry analyses were carried out. DPP-IVlike activity as well as DPP-IV/CD26, FAP- $\alpha$ and CXCR4 proteins in non-tumorous brain are either absent or present at trace levels except some solitary segments of the capillary/ vascular bed, as best evident for DPP-IV enzymatic activity histochemistry, also in the surrounding pericyte-like cells. In contrast, significant up-regulation of DPP-IV enzymatic activity (Fig. 4) and expression of DPP-IV/CD26, FAP- $\alpha$ and CXCR4 proteins (Table IV) is evident in both vascular and parenchymal tissue compartments of WHO grade IV tumours (Fig. 5). In most tumour samples substantial intra-specimen variation in staining density was observed for all molecules studied.

Extent of neovascularization and necrosis represent morphological indicators used for astrocytoma tumour grading. Expected positive correlation between the tumour

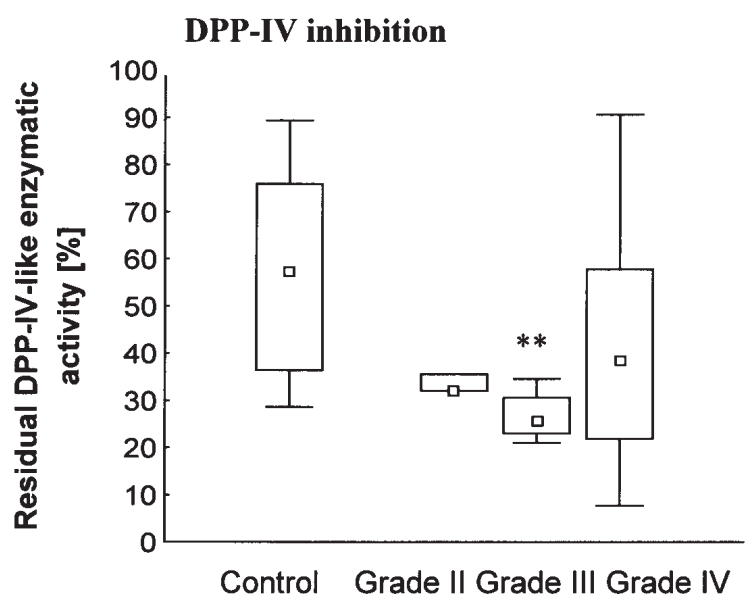

\section{DPP8/9 inhibition}

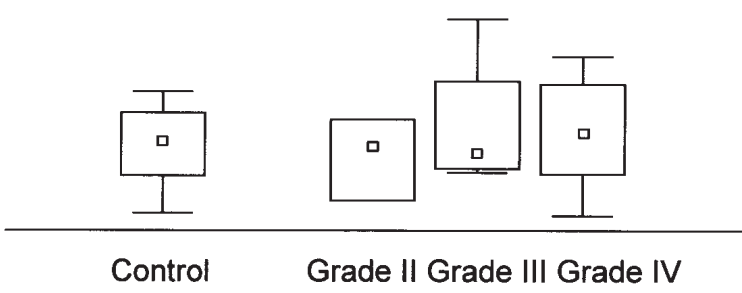

Figure 3. Residual DPP-IV-like enzymatic activity after DPP-IV and DPP8/9 inhibition. Squares, medians; boxes, middle 25-75\% of measured values; bars, minimal resp maximal values; $\mathrm{p}$, compared to controls; ${ }^{*} \mathrm{p}<0.05$; Mann-Whitney U test. 

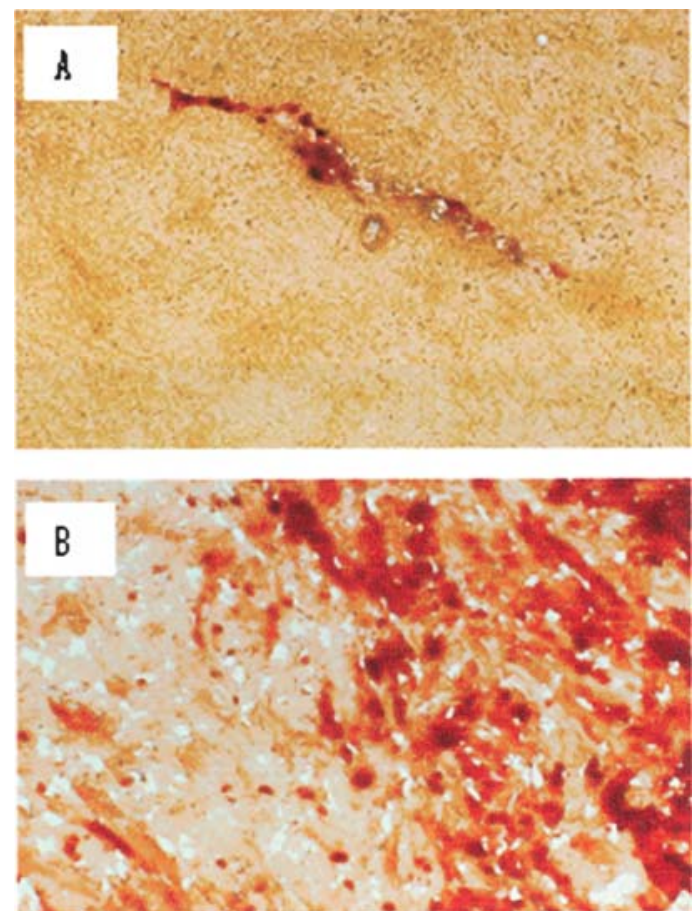

Figure 4. Localization of DPP-IV in non-tumorous (A) and glioblastoma WHO grade IV (B) tissues by enzymatic activity histochemistry. Original magnification $\mathrm{x} 200$.
Table IV. Enzymatic activity histochemistry a and immunohistochemistry ${ }^{b}$ of DPP-IV, FAP- $\alpha$, and CXCR4 in human astrocytic tumours and non-tumorous brain tissues.

\begin{tabular}{lcccc}
\hline & $\begin{array}{c}\text { DPP-IV- } \\
\text { like }^{\mathrm{a}}\end{array}$ & $\begin{array}{c}\text { DPP-IV/ } \\
\text { CD26 }\end{array}$ & FAP- $^{\mathrm{b}}$ & CXCR4 $^{\mathrm{b}}$ \\
\hline Non-malignant & Traces & Traces & Traces & Traces \\
Grade II & ++ & +++ & Traces & +++ \\
Grade III & ++ & ++++ & +++ & ++ \\
Grade IV & ++++ & +++ & +++ & ++++ \\
\hline
\end{tabular}

Values represent modus values of individual samples. Staining intensities were scored as shown in Materials and methods.

grade and both these parameters was indeed observed in our experimental cohort (Table III). There was a substantial degree of correlation of DPP-IV enzymatic activity reached with both vascularization and with relative occurrence of necrosis (Table III). A similar trend was observed for DPP-IV, FAP- $\alpha$ and CXCR4 mRNA expression.
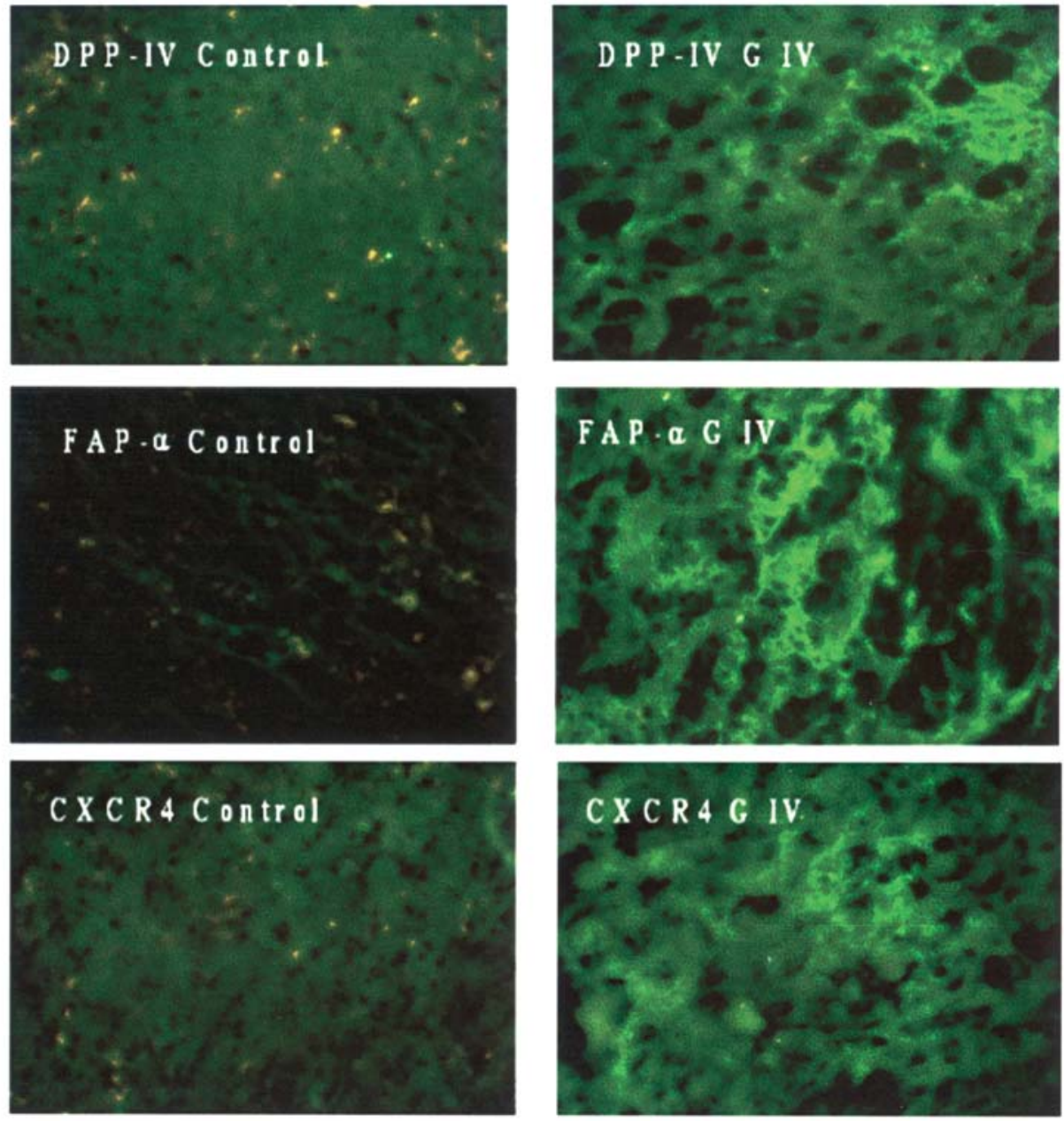

Figure 5. Detection of DPP-IV, FAP- $\alpha$, and CXCR4 in non-tumorous and glioblastoma Grade IV tissues by immunohistochemistry. Original magnification x400. 


\section{Discussion}

Increased DPP-IV expression and activity has so far been reported in multiple types of cancer, including thyroid, skin and prostate and in some white blood cell-derived malignancies (5). In contrast, decreased DPP-IV expression was observed in melanoma, endometrial adenocarcinoma and non-small cell lung cancer cell lines (21-23). It has been suggested that the balance of inhibitory and stimulatory proteolytic regulation by DPP-IV can have profound effects upon the available soluble growth stimulatory and growth inhibitory factors within the normal microenvironment with drastic consequences if a tumourigenic event occurs (21). Altering the balance of DPP-IV enzymatic activity therapeutically may have significant beneficial effects, as has already been demonstrated in diabetes (24) and suggested for rheumatoid arthritis (4).

In this report, we established that DPP-IV activity represented by several 'Dipeptidyl peptidase-IV activity and/or structure homologues' may be an important therapeutic target for manipulating glioma growth. The observed correlation of DPP-IV and FAP- $\alpha$ mRNA expression fits well with proposed co-regulation of both gene products, where FAP- $\alpha$ upregulation is associated with transfection-induced DPP-IV expression in some cell lines (23). Though in a different cellular context, the identification of DPP-IV-FAP- $\alpha$ heterodimers (25) also indirectly points to the possible functional cooperation of both enzymes. Compared to the non-malignant brain tissue, substantial upregulation of DPP-IV/CD26 and FAP- $\alpha$ expression associated with significantly higher DPPIV-like enzymatic activity was observed in grade IV gliomas. Moreover, results of the inhibition studies strongly suggest that plasma membrane DPP-IV/CD26 and FAP- $\alpha$ are responsible for the DPP-IV-like enzymatic activity identified in highgrade tumours. Since there is no specific inhibitor, FAP- $\alpha$ participation can not be precisely quantified, but the weaker correlation of FAP- $\alpha$ rather than DPP-IV/CD26 mRNA expression with the whole DPP-IV-like activity argues for a relatively minor contribution of FAP- $\alpha$. Thus, plasma membrane DPP-IV/CD26 probably represents most of the DASH cleavage activity for susceptible local growth mediators in glioblastoma. Considering the marked effect of the DPP8/9 selective inhibitor, the participation of intracellularly localized DPPs 8 and 9 in astrocytic tumours is apparent. Even in nonmalignant tissues the DPP8/9 activity probably represents the dominant component of all cell-associated DASH hydrolytic activity. Nonetheless, as mentioned before, the functional targets of the intracellular and extracellular DASH molecules presumably differ.

The presence of CXCR4 and SDF- $1 \alpha$ were observed across a range of tumours. The pro-malignant potential of the CXCR4-SDF1 axis was noted in the results of Luker and Luker (9), who documented decreased breast cancer growth as a consequence of reduced CXCR4 expression. CXCR4 tumour grade-associated expression has already been reported in gliomas $(26,27)$. The first evidence of a possible functional link of the two so far separately studied molecular groups, chemokine system and DASH molecules, was given by Herrera et al (15) who found both structural association as well as a functional relationship of CXCR4 and DPP-IV in
T-cells, where both molecules are internalized together upon the SDF- $1 \alpha$-mediated signaling. The functional relation of DPP-IV and the CXCR4-SDF-1 $\alpha$ axis in transformed cells was later suggested by several authors (28). In this study, we identified a significant correlation between the chemokine receptor CXCR4 and DPP-IV expression and even tighter correlation between the CXCR4 expression and DPP-IV enzymatic activity in glioblastoma. The marked upregulation of CXCR4 tightly correlating with DPP-IV might be interpreted as a compensation of DPP-IV activity-caused degradation and thus decreased availability of SDF- $1 \alpha$ within the tumour microenvironment. Indeed, inverse correlation of CXCR4 and SDF- $1 \alpha$ expression with the tumour grade previously observed in human endometrial adenocarcinoma was associated with DPP-IV downregulation (22).

Our findings indicate that the DPP-IV-like enzymatic activity in human brain and glioma tissues represents conjunction of hydrolytic action of several DASH members. Moreover, the increase of the hydrolytic activity in glioblastoma compared to non-malignant tissue is probably mostly derived from upregulation of canonical DPP-IV. However, the modification of DPP-IV biologically active substrate turnover at the local level might be counterbalanced by consequent regulation of their receptors. Nevertheless, our observations open up the possibility that pharmacological regulation of DPP-IV-mediated modulation of SDF-1 $\alpha$ function may alter glioma cell migration, providing insight into downstream therapeutic modalities.

\section{Acknowledgements}

The authors wish to thank Dr Jonathan Duke-Cohan from Dana Farber Cancer Institute, Harvard School of Medicine, USA, for critical reading of the manuscript and valuable suggestions and Dr Jaroslav Vorlicek from Institute of Physiology, Academy of Sciences, Czech Republic for his assistance with the statistical analysis. The work was supported by grants IGA NR/8105-3 and MSMT 0021620808 .

\section{References}

1. Sedo A and Malik R: Dipeptidyl peptidase IV-like molecules: homologous proteins or homologous activities? Biochim Biophys Acta 1550: 107-116, 2001.

2. Boonacker E and van Noorden CJ: The multifunctional or moonlighting protein CD26/DPPIV. Eur J Cell Biol 82: 53-73, 2003.

3. Dang NH and Morimoto C: CD26: An expanding role in immune regulation and cancer. Histol Histopathol 17: 1213-1226, 2002 .

4. Sedo A, Duke-Cohan JS, Balaziova E and Sedova LR: Dipeptidyl peptidase IV activity and/or structure homologs: contributing factors in the pathogenesis of rheumatoid arthritis? Arthritis Res The 7: 253-269, 2005 .

5. Busek P, Malik R and Sedo A: Dipeptidyl peptidase IV activity and/or structure homologues (DASH) and their substrates in cancer. Int J Biochem Cell Biol 36: 408-421, 2004.

6. Wesley UV, Albino AP, Tiwari S and Houghton AN: A role for dipeptidyl peptidase IV in suppressing the malignant phenotype of melanocytic cells. J Exp Med 190: 311-322, 1999.

7. Salmaggi A, Gelati M, Pollo B, et al: CXCL12 in malignant glial tumors: a possible role in angiogenesis and cross-talk between endothelial and tumoral cells. J Neurooncol 67: 305-317, 2004. 
8. Kucia M, Jankowski K, Reca R, et al: CXCR4-SDF-1 signalling, locomotion, chemotaxis and adhesion. J Mol Histol 35: 233-245, 2004.

9. Luker KE and Luker GD: Functions of CXCL12 and CXCR4 in breast cancer. Cancer Lett 238: 30-41, 2006.

10. Robledo MM, Bartolome RA, Longo N, et al: Expression of functional chemokine receptors CXCR3 and CXCR4 on human melanoma cells. J Biol Chem 276: 45098-45105, 2001.

11. Eisenhardt A, Frey U, Tack M, et al: Expression analysis and potential functional role of the CXCR4 chemokine receptor in bladder cancer. Eur Urol 47: 111-117, 2005.

12. Zhou Y, Larsen PH, Hao C and Yong VW: CXCR4 is a major chemokine receptor on glioma cells and mediates their survival. J Biol Chem 277: 49481-49487, 2002.

13. Ehtesham M, Winston JA, Kabos P and Thompson RC: CXCR4 expression mediates glioma cell invasiveness. Oncogene 25: 2801-2806, 2006.

14. Christopherson KW II, Hangoc G and Broxmeyer HE: Cell surface peptidase CD26/dipeptidylpeptidase IV regulates CXCL12/stromal cell-derived factor- 1 alpha-mediated chemotaxis of human cord blood CD34+ progenitor cells. J Immunol 169: 7000-7008, 2002

15. Herrera C, Morimoto C, Blanco J, Mallol J, Arenzana F, Lluis C and Franco R: Comodulation of CXCR4 and CD26 in human lymphocytes. J Biol Chem 276: 19532-19539, 2001.

16. Livak KJ and Schmittgen TD: Analysis of relative gene expression data using real-time quantitative PCR and the $2^{-\Delta \Delta C T}$ method. Methods 25: 402-408, 2001.

17. Sedo A, Krepela E and Kasafirek E: A kinetic fluorometric assay of dipeptidyl peptidase IV in viable human blood mononuclear cells. Biochimie 71: 757-761, 1989.

18. Lowry OH, Rosebrough NJ, Farr AL and Randall RJ: Protein measurement with the folin phenol reagent. J Biol Chem 193: 265-275, 1951.
19. Lojda Z: Proteinases in pathology. Usefullness of histochemical methods. J Histochem Cytochem 29: 481-493, 1981.

20. Jenkins PD, Jones DM and Szelke M: DP-IV-serine protease inhibitors. Patent Application PCT WO95/15309.

21. Iwata S and Morimoto C: CD26/dipeptidyl peptidase IV in context. The different roles of a multifunctional ectoenzyme in malignant transformation. J Exp Med 190: 301-306, 1999.

22. Khin EE, Kikkawa $\mathrm{F}$, Ino $\mathrm{K}$, et al: Dipeptidyl peptidase IV expression in endometrial endometrioid adenocarcinoma and its inverse correlation with tumor grade. Am J Obstet Gynecol 188: 670-676, 2003.

23. Wesley UV, Tiwari S and Houghton AN: Role for dipeptidyl peptidase IV in tumor suppression of human non-small cell lung carcinoma cells. Int J Cancer 109: 855-866, 2004.

24. Wiedeman PE and Trevillyan JM: Dipeptidyl peptidase IV inhibitors for the treatment of impaired glucose tolerance and type 2 diabetes. Curr Opin Investig Drugs 4: 412-420, 2003.

25. Ghersi G, Dong H, Goldstein LA, Yeh Y, Hakkinen L, Larjava HS and Chen WT: Regulation of fibroblast migration on collagenous matrix by a cell surface peptidase complex. J Biol Chem 277: 29231-29241, 2002.

26. Rempel SA, Dudas S, Ge S and Gutierrez JA: Identification and localization of the cytokine SDF1 and its receptor, CXC chemokine receptor 4 , to regions of necrosis and angiogenesis in human glioblastoma. Clin Cancer Res 6: 102-111, 2000

27. Yang SX, Chen JH, Jiang XF, et al: Activation of chemokine receptor CXCR4 in malignant glioma cells promotes the production of vascular endothelial growth factor. Biochem Biophys Res Commun 335: 523-528, 2005.

28. Mizokami Y, Kajiyama H, Shibata K, Ino K, Kikkawa F and Mizutani S: Stromal cell-derived factor-1 alpha-induced cell proliferation and its possible regulation by CD26/dipeptidyl peptidase IV in endometrial adenocarcinoma. Int J Cancer 110: 652-659, 2004. 